\title{
Distribusi dan Kelimpahan Parasitoid Telur, Telenomus spp. di Sumatera Barat: Status dan Potensinya Sebagai Agens Pengendali Hayati
}

\author{
EDDY SUSIAWAN DAN NETTI YULIARTI \\ Politeknik Pertanian Universitas Andalas, Jl. Raya Negara KM 7 Tj. Pati \\ Payakumbuh 26271
}

(diterima Desember 2005, disetujui Agustus 2006)

\begin{abstract}
Distribution and Abundance of Egg Parasitoids Telenomus spp. in West Sumatra: Their Status and Potential as Biological Control. Exploration of egg parasitoids was conducted by collecting host eggs from soybean, vegetable crops, peas, corn and rice fields in West Sumatra. We found six species Telenomus distributed throughout studied locations in West Sumatera. Four species have been identified, namely T. remus Nix., T. rowani Gah., T. dignus Gah., T. dignoides Nix., whereas two others have not been identified yet because there is no appropriate identification key. The results showed that the both T. rowani Gah. and T. dignus Gah were distributed in all studied locations with different individual number, but they could be potentially be used as biocontrol agents in the future. The highest numbers of species was found in Tanah Datar and Solok with different abundance, whereas the lowest number of species were in Agam and Lima Puluh Kota.
\end{abstract}

KEY WORDS: exploration, identification, species abundance.

\section{PENDAHULUAN}

Telenomus spp. (Hymenoptera : Scelionidae) merupakan tabuhan kecil, yang biasanya berwarna hitam dan secara eksklusif merupakan parasitoid pada telur serangga lain (Polaszek \& Kimani 1990). Inang Telenomus spp. kebanyakan adalah ordo Lepidoptera dan Hemiptera, namun ada juga yang diketahui muncul dari telur serangga ordo Diptera dan Neuroptera (Johnson 1984).

Telenomus spp. sangat penting dan potensial dalam menekan populasi inangnya yang berupa hama secara alami. Di Indonesia tercatat $T$. rowani Gah. dan T. dignus Gah. yang berperan dalam menekan populasi penggerek batang padi (Kalshoven 1981; Sasmita \& Baehaki 1997). Di Afrika terdapat T. busseolae Polasz. yang memarasit penggerek tanaman serealea (Polaszek et al. 1993) dan di California Selatan, Honda \& Trjapitzin (1995) menemukan T. hugi Hond \& Trjap. dari telur hama alpukat Sabulodes aegrotata (Guenee) (Lepidoptera: Geometridae).

Telenomus spp. panjang tubuhnya lebih kurang $1 \mathrm{~mm}$ (Kalshoven 1981; Polaszek \& Kimani 1990). Ukuran yang sangat kecil ini merupakan hambatan dalam melakukan identifikasi sehingga sering menyebabkan kesalahan dalam identifikasi spesies. Diduga karena ukuran yang 
kecil ini juga menyebabkan penelitian tentang aspek taksonomi dan ekologi parasitoid ini masih sedikit dilaporkan di Indonesia. Penelitian ini dilakukan dengan tujuan untuk mengetahui keanekaragaman, distribusi, dan kelimpahan spesies Telenomus spp. yang terdapat di berbagai Kabupaten di Sumatera Barat. Target khusus lainnya adalah untuk mengkaji keberadaan Telenomus pada berbagai ekosistem pertanaman seperti kedelai, padi, sayur-sayuran, kacang-kacangan, dan jagung.

\section{BAHAN DAN METODE}

\section{Waktu dan Tempat}

Penelitian ini dilaksanakan mulai bulan Maret sampai September 2005 di Sumatera Barat yakni di Kabupaten Lima Puluh Kota, Tanah Datar, Padang Pariaman, Solok, dan Agam.

\section{Metode}

Sampel parasitoid dikoleksi dari pertanaman padi, kedelai, sayursayuran, kacang-kacangan dan jagung milik petani di beberapa lokasi terpilih dengan cara mengoleksi telur inang menggunakan metode transek sepanjang garis $100 \mathrm{~m}$. Telur-telur yang didapat lalu dibawa ke laboratorium dan diinkubasi sampai imago parasitoidnya muncul. Parasitoid yang muncul diidentifikasi dan dihitung jumlah individunya untuk mengetahui kelimpahan serta tingkat parasitisasinya

\section{HASIL DAN PEMBAHASAN}

\section{Hasil}

Eksplorasi parasitoid telur (Telenomus spp.) di beberapa wilayah nagari yang tercakup dalam 20 kecamatan yang tersebar di seluruh Kabupaten Lima Puluh Kota, Kabupaten Padang Pariaman, Kabupaten Agam, Kabupaten Tanah Datar, serta Kabupaten Solok, berhasil mengoleksi telur-telur penggerek batang padi (Scirpophaga spp.), ulat grayak (Spodoptera spp.), dan Hesperidae yang terparasit oleh Telenomus. Setelah dipelajari dan diteliti secara seksama didapatkan parasitoid telur tersebut terdiri dari 6 (enam) spesies yakni $T$. rowani, $T$. dignus, $T$. dignoides, $T$. remus, serta dua spesies lainnya yang belum berhasil diidentifikasi dengan pasti, dan untuk selanjutnya dalam laporan ini disebut sebagai Telenomus sp-1 dan sp-2 (Tabel 1).

Dari seluruh spesies Telenomus yang ditemukan tersebut, T. rowani yang memarasit telur Scirpophaga merupakan spesies yang memiliki kelimpahan individu paling tinggi serta tersebar di seluruh Kabupaten yang dijadikan lokasi penelitian. Sebaliknya T. remus yang memarasit telur Spodoptera hanya ditemukan di satu lokasi, yaitu Kecamatan Banuhampu (Agam), dan merupakan spesies Telenomus dengan 
kelimpahan individu paling rendah (Gambar 1 dan 3).

Adapun spesies Telenomus yang paling sering ditemukan muncul dari telur-telur penggerek batang padi secara bersama-sama adalah $T$. rowani dan $T$. dignus. Jika dibandingkan dengan yang lain, kedua spesies tersebut ternyata juga lebih mampu menyebar dan beradaptasi pada ekosistem pertanian di berbagai wilayah kecamatan dari seluruh kabupaten yang ada. $T$. dignoides yang juga menyerang penggerek batang padi hanya ditemukan di beberapa lokasi tertentu. Begitu pula keadaan Telenomus sp-1 dan sp-2, kedua spesies ini memarasit telur Hesperidae dan hanya ditemukan di beberapa lokasi. Untuk lebih jelasnya, persebaran Telenomus di Sumatera Barat dapat dilihat pada Tabel 1 dan Gambar 1.

Pada Tabel 1 juga dapat dilihat bahwa parasitoid Telenomus bersifat spesifik inang; yang berarti setiap spesies hanya memarasit satu jenis inang. Namun, sebaliknya pada tabel tersebut juga memperlihatkan bahwa satu jenis inang dapat diserang oleh lebih dari satu jenis parasitoid.

Tabel 1. Telenomus dan persebarannya di berbagai kecamatan di Sumatera Barat

\begin{tabular}{|c|c|c|c|c|}
\hline No. & Spesies & Inang & $\begin{array}{l}\text { Tanaman } \\
\text { Inang }\end{array}$ & Lokasi (Kecamatan) \\
\hline 1. & T. rowani & Scirpophaga spp. & Padi & $\begin{array}{l}\text { Akabiluru, Baso, Harau, Payakumbuh, } \\
\text { Lareh Sago Halaban, Luhak, } \\
\text { Rambatan, Salimpaung, Sungai Tarab, } \\
\text { Gunung Talang, Bukit Sundi (Muaro } \\
\text { Paneh), Kubung (Koto Baru), Batang } \\
\text { Anai,Lubuk Alung, Nan Sabaris, Kurai, } \\
\text { Ampek Angkek, Ampek Koto }\end{array}$ \\
\hline 2. & T. dignus & Scirpophaga spp. & Padi & $\begin{array}{l}\text { Akabiluru, Baso, Harau, Payakumbuh, } \\
\text { Lareh Sago Halaban, Luhak, } \\
\text { Rambatan, Salimpaung, Sungai Tarab, } \\
\text { Gunung Talang, Bukit Sundi (Muaro } \\
\text { Paneh), Kubung (Koto Baru), Batang } \\
\text { Anai, Lubuk Alung, Nan Sabaris, } \\
\text { Kurai, Ampek Angkek, Ampek Koto }\end{array}$ \\
\hline 3. & T. dignoides & Scirpophaga spp. & Padi & $\begin{array}{l}\text { Harau, Akabiluru, Luhak, Lareh Sago } \\
\text { Halaban, Salimpaung, Sungai Tarab, } \\
\text { Bukit Sundi (Muaro Paneh), Nan } \\
\text { Sabaris, Kurai, Banuhampu, Rambatan }\end{array}$ \\
\hline 4. & T. remus & Spodoptera litura & Kubis & Gunung Talang \\
\hline 5. & Telenomus sp-1 & Hesperiidae & Padi & $\begin{array}{l}\text { Batang Anai, Ampek Koto, Gunung } \\
\text { Talang, Rambatan }\end{array}$ \\
\hline 6. & Telenomus sp-2 & Hesperidae & Padi & Sungai Tarab \\
\hline
\end{tabular}


1. Kelimpahan dan Dominasi Telenomus spp. di Berbagai Daerah di Sumatera Barat.

Pada Gambar 2 di bawah ini dapat dilihat proporsi kelimpahan parasitoid Telenomus yang dikumpulkan di berbagai Kabupaten di Sumatera Barat. Dalam penelitian ini berhasil menemukan/mengoleksi sebanyak 9272 individu Telenomus yang terdiri atas enam spesies. Dari jumlah tersebut urutan proporsi kelimpahan individu Telenomus adalah sebagai berikut: Kabupaten Tanah Datar (40,36\%), Solok (20,10\%), Padang Pariaman (20,06\%), Lima Puluh Kota $(18,12 \%)$, sedangkan jumlah atau kelimpahan individu paling sedikit dijumpai di Kabupaten Agam (1,36\%).

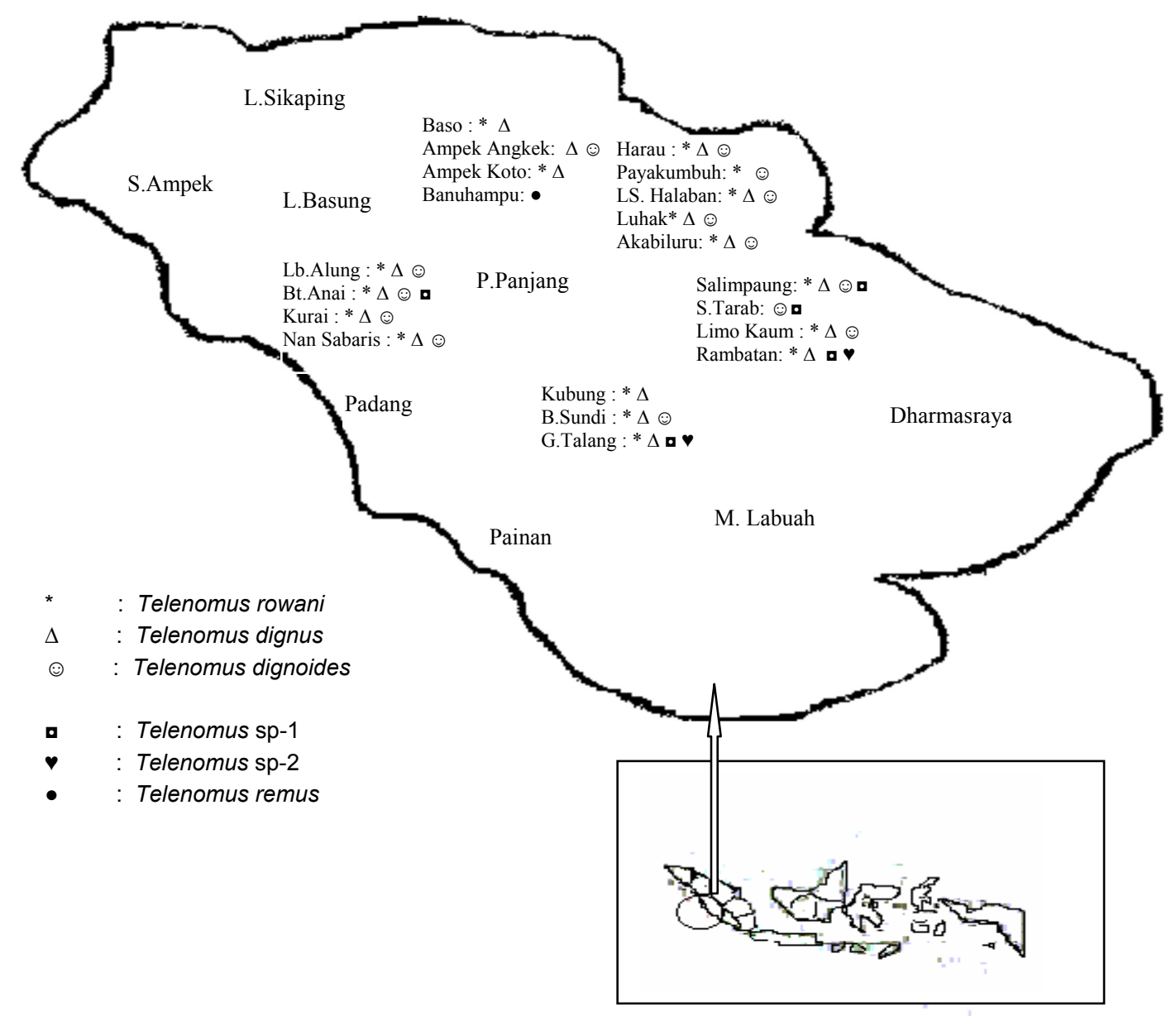

Gambar 1. Peta persebaran Telenomus spp. di Sumatera Barat 


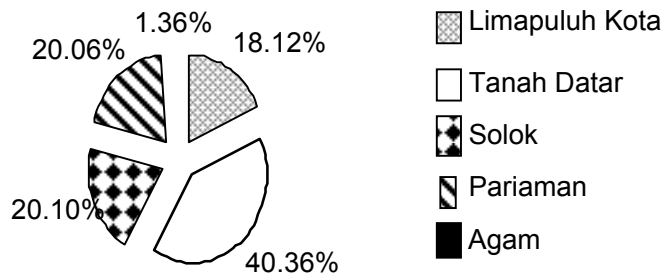

Gambar 2. Proporsi kelimpahan Telenomus di berbagai Kabupaten di Sumatera Barat.

Kelimpahan spesies atau jumlah individu parasitoid yang ditemukan di suatu daerah tidak selalu berkorelasi dengan jumlah spesies (ragam jenis parasitoid) yang ditemukan pada daerah tersebut. Sebagai contoh, di Kabupaten Solok dan Padang Pariaman yang memiliki kelimpahan individu hampir sama yakni 1864 dan 1860 ekor parasitoid, mempunyai jumlah spesies yang berbeda. Pada Tabel 2 dapat dilihat bahwa Kabupaten Lima Puluh Kota mempunyai jumlah spesies yang sama dengan di Kabupaten Agam; namun jumlah individu yang ditemukan jauh lebih banyak di Kabupaten Lima Puluh Kota. Lebih jauh dapat dikatakan bahwa tingginya jumlah individu yang ditemukan bisa saja disusun oleh hanya satu spesies tetapi mempunyai kelimpahan yang tinggi.

Pada penelitian ini didapatkan sesuatu yang menarik dimana kekayaan spesies tertinggi juga diikuti oleh kelimpahan individu yang tinggi. Begitu pula jumlah spesies di Kabupaten Agam yang paling rendah sekaligus juga mempunyai kelimpahan individu yang rendah.

\section{Kelimpahan Telenomus pada Berbagai Inang}

Berdasarkan hasil eksplorasi didapatkan 3 macam inang Telenomus yakni Scirpophaga sp., Hesperidae (Lepidoptera), dan Spodoptera (ulat grayak). Gambar 3 memperlihatkan bahwa Telenomus yang berasal dari telur penggerek batang padi (Scirpophaga sp.) adalah paling tinggi kelimpahannya dibandingkan 2 jenis inang lainnya.

Tabel 2. Jumlah spesies yang ditemukan dan kelimpahan individu Telenomus di berbagai Kabupaten di Sumatera Barat

\begin{tabular}{lcc}
\hline Kabupaten & $\begin{array}{c}\text { Jumlah spesies } \\
(\text { macam })\end{array}$ & $\begin{array}{c}\text { Kelimpahan } \\
\text { (ekor) }\end{array}$ \\
\hline Lima Puluh Kota & 3 & 1680 \\
Tanah Datar & 5 & 3742 \\
Solok & 5 & 1864 \\
Padang Pariaman & 4 & 1860 \\
Agam & 3 & 126 \\
\hline Total & & 9272 \\
\hline
\end{tabular}




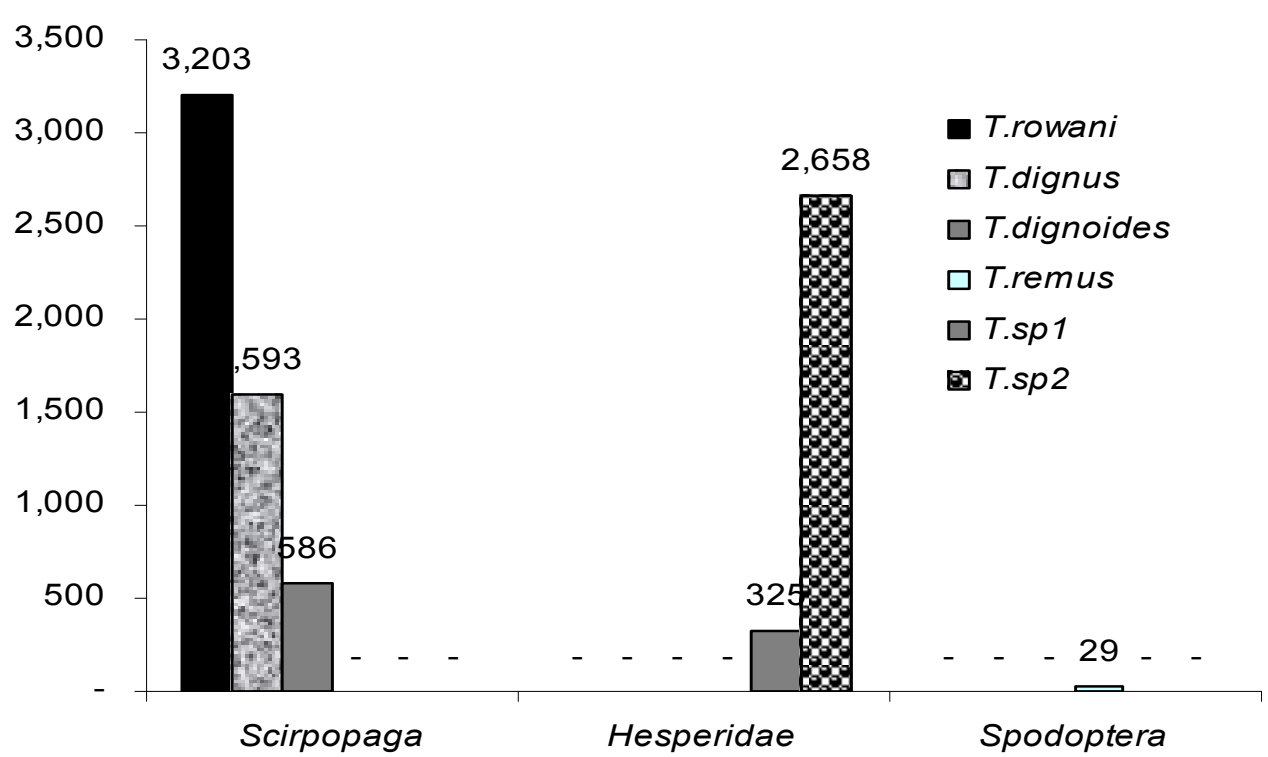

Gambar 3. Kelimpahan Telenomus pada berbagai jenis inang

\section{Pembahasan}

Dari semua spesies Telenomus yang diperoleh, $T$. rowani dan $T$. dignus adalah 2 spesies yang selalu ditemukan di semua kecamatan yang dijadikan lokasi penelitian, sedangkan T. dignoides hanya ditemukan di beberapa kecamatan (Tabel 1). Diketahui ketiga spesies ini berinang telur penggerek batang padi (Scirpophaga sp.). Sasmita \& Baehaki (1997) melaporkan dua spesies Telenomus pada penggerek batang padi putih di Sukamandi yaitu $T$. rowani dan $T$. dignus. Selanjutnya Kalshoven (1981) menyatakan bahwa satu kelompok telur penggerek batang padi putih yang biasanya berjumlah sekitar 200 telur, 50-75\% diantaranya terparasit dan parasitoid tersebut diyakini sebagai $T$. rowani dan $T$. dignoides. Yuliarti (2002) juga melaporkan keberadaan ketiga spesies tersebut dari beberapa daerah di Jawa. Nampaknya ketiga spesies parasitoid tersebut cukup mampu beradaptasi pada berbagai ekosistem pertanian sehingga mudah tersebar di beberapa wilayah serta potensial sebagai agens hayati di Jawa dan Sumatera.

Di sisi lain, $T$. remus merupakan spesies parasitoid yang paling jarang ditemukan (Tabel 1 dan 2). Spesies ini diketahui keberadaannya hanya di Kecamatan Banuhampu (Agam). Tercatat pada saat eksplorasi di lapangan, inang dari parasitoid ini (Spodoptera sp.) sangat berlimpah, namun dari telur-telur yang didapatkan dan diinkubasi di laboratorium umumnya hanya menetaskan larva Spodoptera tanpa ada satupun parasitoidnya. Kenyataan ini amat disayangkan karena dalam hal ini 
berarti pengaruh faktor pengatur padat populasi serangga inang (hama) tidak bekerja secara optimal. Biasanya laju kepadatan populasi parasitoid mengikuti kepadatan populasi inangnya secara fluktuatif. Oleh karena itu diduga kondisi ini sebagai akibat praktik penggunaan pestisida yang intensif dan tidak rasional terutama pada areal pertanaman sayuran.

Selain pengaruh praktek budidaya, kelimpahan populasi $T$. remus yang rendah di Sumatera Barat bisa juga disebabkan oleh tingkat kemampuan adaptasi lokal serta persebaran parasitoid yang relatif rendah. Perbedaan tingkat parasitisasi antar lokasi menunjukkan adanya perbedaan kemampuan adaptasi lokal, khususnya bagi spesies-spesies yang memiliki kemampuan dispersal rendah (Kruess 2003) mengemukakan bahwa perbedaan kelimpahan spesies antar lokasi menunjukkan adanya adaptasi lokal, khususnya bagi spesies yang kemampuan migrasinya rendah. Dalam kaitan ini, eksplorasi parasitoid yang telah dilakukan berhasil mengumpulkan lebih dari 200 kelompok telur Spodoptera. Setelah diinkubasi di laboratorium ternyata dari dalam telur inang tersebut tidak satupun muncul parasitoid. Berdasarkan informasi yang diperoleh dari masyarakat serta pengamatan lapangan secara cermat dapat dikemukakan bahwa tradisi penyemprotan tanaman dengan pestisida secara terjadwal 2 kali seminggu (jika musim hujan ditingkat- kan 2 hari sekali) menyebabkan parasitoid tidak mampu lagi bertahan hidup. Akibatnya peran sebagai pengatur padat populasi inang (hama) oleh parasitoid tidak dapat bekerja secara normal.

Keberadaan, kekayaan dan kelimpahan individu, serta keanekaragaman parasitoid pada ekosistem pertanian untuk mengatur populasi inangnya dipengaruhi oleh berbagai faktor seperti garis lintang dan ketinggian (Noyes 1989; Skillen, Pickering, dan Sharkey 2000), praktek budidaya yang dilakukan (Ostman et al. 2001), pola penggunaan lahan (Usher 1993), tanaman pinggir (Thomas \& Marshall 1999), serta kondisi lansekap pertanian (Altieri 1999). Oleh sebab itu, kekayaan, keanekaragaman, persebaran, dan kelimpahan spesies bervariasi menurut tempat dan selang waktu pengambilan contoh (Rieske \& Buss 2001).

Seperti diketahui, wilayah di sepanjang jalan raya Padang Panjang Bukitinggi sebelumnya merupakan salah satu sentra pertanian tanaman sayuran dan padi bagi Kabupaten Agam, tetapi sejak 5 tahun belakangan mengalami perubahan pesat menjadi areal pertokoan dan bangunan perumahan. Diduga hal ini (selain penggunaan pestisida dan pupuk kimia yang intensif) berpengaruh terhadap keanekaragaman spesies yang terdapat pada lansekap pertanian Kabupaten Agam. 
Kelimpahan individu parasitoid di Kabupaten Tanah Datar menunjukkan angka yang paling tinggi dengan proporsi kelimpahan 40,36\% (Gambar 2) dengan jumlah individu sebanyak 3742 (Tabel 2). Hal ini jauh berbeda dengan Kabupaten Agam yang proporsi kelimpahan parasitoidnya hanya $1,36 \%$ dengan jumlah 126 individu $T$. remus saja. Jika diamati lebih jauh parasitoid penghuni lansekap pertanian di kedua kabupaten ini memang sangat berbeda. Di Kabupaten Agam komponen penyusun lansekap pertaniannya telah banyak mengalami perubahan akibat ulah manusia dalam mewujudkan egonya. Diduga modifikasi ekosistem lansekap dan habitat yang terfragmentasi menjadi salah satu faktor penyebab menurunnya kelimpahan spesies dan persebarannya. Selain itu, pengaruh praktek budidaya yang mengandalkan bahan kimia juga dapat menjadi penyebab menurunnya populasi musuh alami hama khususnya parasitoid.

Jika dilihat dari aspek dominasi Telenomus di berbagai Kabupaten, secara umum pada Gambar 3 terlihat bahwa kelimpahan Telenomus paling tinggi adalah $T$. rowani yang memarasit telur-telur penggerek batang padi. $T$. rowani dan $T$. dignus mendominasi hampir semua wilayah sasaran penelitian dibanding spesies lainnya.
Pada Gambar 3 juga terlihat dominasi Telenomus sp-2 yang berasal dari telur Hesperidae. Hal ini menarik untuk dicermati karena parasitoid ini hanya ditemukan di dua lokasi yakni Kabupaten Solok dan Tanah Datar. Jika diamati lebih jauh pada Gambar 4 terlihat tingkat parasitisasinya yang sangat tinggi $(46,17 \%)$ jauh melebihi kemampuan $T$. rowani dalam hal memarasit inangnya $(17,36 \%)$. Yuliarti (2002) juga melaporkan keberadaan Telenomus sp-3 asal telur Hesperidae dari Jawa (Bantul) yang mempunyai ciri-ciri yang sama dengan Telenomus sp-2 dengan tingkat parasitisasi $29,05 \%$.

Hal yang juga menarik dari hasil penelitian ini adalah bahwa persentase parasitisasi Telenomus di Sumatera Barat cukup tinggi pada hama yang tidak banyak menimbulkan masalah. Baik Hesperidae maupun penggerek batang padi adalah hamahama yang tidak tergolong menimbulkan kerusakan berat pada tanaman inangnya.

Sebaliknya, Spodoptera litura pada berbagai jenis sayuran dan $S$. exigua pada bawang daun maupun bawang merah yang sangat merusak dan selalu menimbulkan masalah di Kabupaten Agam serta Tanah Datar justru mempunyai parasitoid (musuh alami) dengan kemampuan parasitisasi yang rendah. 


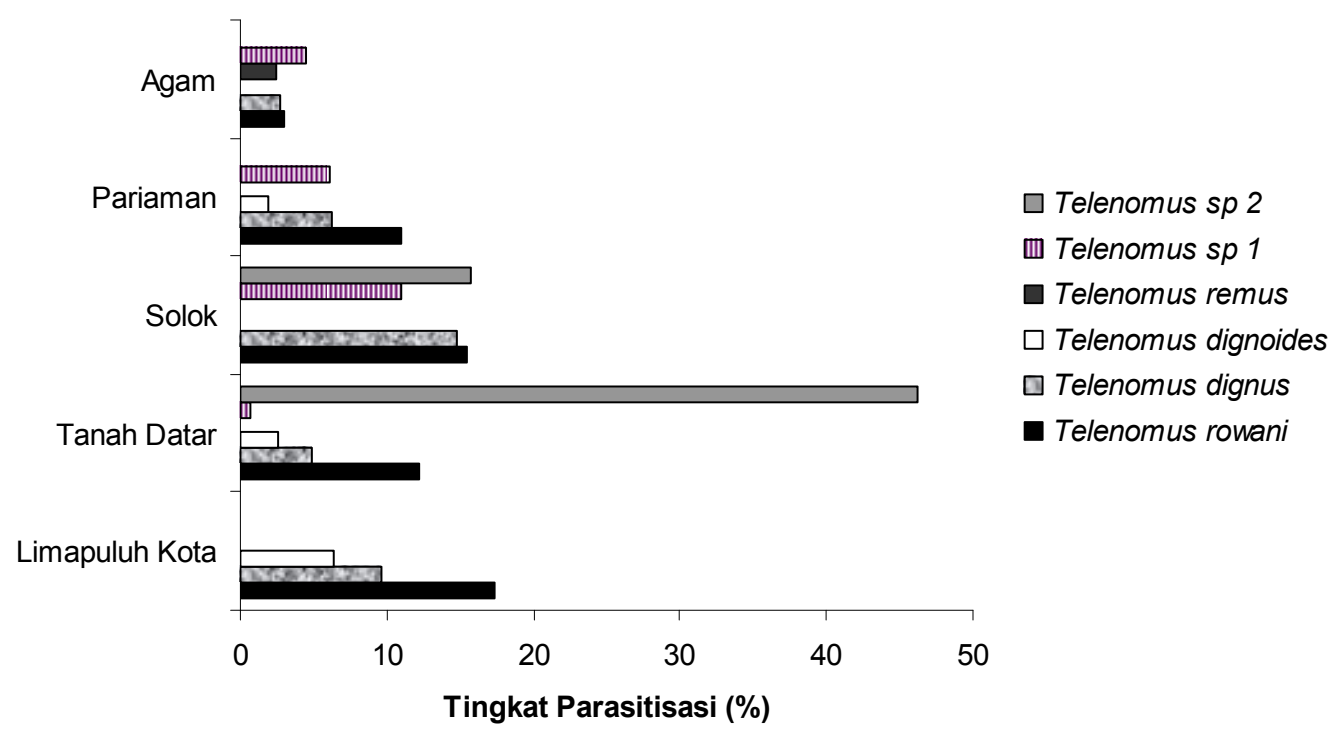

Gambar 4. Tingkat parasitisasi Telenomus (\%) di Sumatera Barat

Setidaknya, hasil penelitian ini menuntut adanya tindakan lebih lanjut guna mengkaji dan mengembangkan potensi Telenomus yang sudah berhasil dieksplorasi. Spesies yang mempunyai kemampuan parasitisasi yang relatif cukup tinggi seperti T. rowani, T. dignus, dan Telenomus sp-2 harus tetap terpelihara dan terjaga kelestariannya. $T$. remus yang masih rendah kelimpahan populasi maupun kemampuan parasitisasinya dapat ditingkatkan melalui tindakan konservasi, melakukan pembiakan secara masal di laboratorium, augmentasi baik dalam bentuk inokulasi ataupun inundasi.

\section{KESIMPULAN}

Pada kawasan pertanian tanaman pangan di Sumatera Barat (Kabupaten Agam, Lima Puluh Kota,
Padang Pariaman, Solok, dan Tanah Datar) ditemukan parasitoid telur, Telenomus spp. dengan berbagai tingkat parasitasi, keragaman spesies, maupun kelimpahan populasi, karena itu perlu dikonservasi agar peran dan potensinya sebagai agens hayati dalam pengendalian hama dapat diberdayakan serta ditingkatkan.

\section{DAFTAR PUSTAKA}

Johnson NF. 1984. Systematics of nearctic Telenomus: Clasification and revision of the podisi and phymatae group. Bull of the Obio Biological and Survey 6 (3): 1-113

Honda JY, Trjaptzin SV. 1995. A species description and biological comparison between a new species of Telenomus haliday (Hymenoptera: Scelionidae) and Trichogramma platneri Nagarkatti (Hymenoptera: Trichogrammatidae): Two egg parasitoids of Sabulodes aegrotata (Guene) (Lepidoptera: Geometridae). Pan Pacific Entomol 71 (4): 227-236 
Kalshoven LGE. 1981. The pests of crops in Indonesia. Revised and translated by PA van der Laan. Jakarta

Kruess A. 2003. Effects of landscape structure and habitat type on a plant herbivore parasitoid community. Ecography 26: 283-290

Laba IW, Kartohardjono A, Djatnika K. 1997. Potensi Tetrastichus schoenobii Ferr., Telenomus rowani Gah. dan Trichogramma japonicum Ashm. sebagai parasitoid telur penggerek batang padi kuning (Scirpophaga incertulas Walk.) in Prosiding Seminar Nasional: Tantangan Entomologi Abad XXI. PEI Cabang Bogor. Jan. 1997. pp. 6-27

Menalled FD, Marino PC, Gage SH, Landis DA. 1999. Does agricultural landscape structure affect parasitism and parasitoid diversity. Ecol Appli 9(9): 634-641

Noyes JS. 1989. The diversity of Hymenoptera in the tropic with special reference to parasitica in Sulawesi. Ecol Entomol 14:197-207.

Ostman O, Ekbom B, Bengtsson J. 2001. Landscape heterogenity and farming practice influence biological control. Basic Appl Ecol 2: 365-371

Polaszek A, Kimani SW. 1990. Telenomus species (Hymenoptera : Scelionidae) in Africa : a review and guide to identification. Bull of Entomol Res 80: 57-71

Polaszek A, Ubeku JA, Perez AB. 1993. Taxonomy of the Telenomus busseolae species-complex (Hymenoptera: Scelionidae)
Rieske LK, Buss LJ. 2001. Influence of site on diversity and abundance of ground and litter-dwelling Coleoptera in Applachin oak-hickory forest. Environ Entomol 30 (3): 484-494

Sasmita P, Baehaki SE. 1997. Kemampuan individu parasitoid telur penggerek padi putih Scirpophaga innotata Wlk. Dan fluktuasinya di pertanaman padi. Prosiding Seminar Nasional PEI Cab. Bogor. pp.177-187

Skillen EL, Pickering J, Sharkey MJ. 2000. Species richness of the Campopleginae and Ichneumonidae (Hymenoptera: Ichneumonidae) along a latitudinal gradient in Eastern North American old-growth forest. Environ Entomol 29 (3): 460-466

Thomas CFG, Marshall EJP.1999. Arthropod abundance and diversity in differently vegetated margins of arable fields. Agri c Ecol and Environt 72: 131-144

Usher MB. 1995. A world of change: landuse patterns and arthropods communities. In: Harrington R, Stork $\mathrm{NE}$, editors. Insect in a changing environment New York: Academic Press. pp. 371-397

Yuliarti N. 2002. Karakter morfologi dan molekuler parasitoid telur, Telenomus spp. (Hymenoptera: Scelionidae) dari beberapa daerah di Jawa. [Tesis]. Bogor. Program Pascasarjana IPB. 